\title{
The Comparison of theMaterials in Styles of Iranian Architecture and its Effect on the Form of the Building before the Islam's Entry to Iran
}

\author{
${ }^{1}$ Mohd Hamdan Ahmad, ${ }^{2}$ Malsiah Hamid, ${ }^{3}$ Mehdi Hanafi Koumleh, \\ ${ }^{4}$ Nora Roostapoor \\ ${ }^{1,2,3}$ Department of Architecture, Faculty of Build Environment, University Teknologi Malaysia, 81310 UTM \\ Skudai, Johor, Malaysia \\ ${ }^{4}$ Department of Architecture, Islamic Azad University, AstanehAshrafieh Branch, Iran
}

\begin{abstract}
During the history,different elements have been determined as influential factors affecting the architecture in different areas. The historical events and political alterations as well as religious and economical changes can directly lead to the architecture style. One of the historical countries with rich architectural history that can be increasingly exposed to more alterations is Iran. In general the architecture styles in Iran can be categorised in six groups. These groups can be divided in two periods before and after Islam's emergence in Iran. The "Parsi" and "Parti" architecture styles belong to the former period and "Razi", "Khorasani", "Isfahani" and "Azari" were common in the latter period, after Islam. Such alterations brought in a variety of architecture styles, in this country, due to theoretical alterations. Furthermore, some novel architectural styles were resulted from a number of physical conditions which had also effects on the theoretical architecture. The current research intends to put an emphasize on the alterations in materials used in two historical periods of Iran, "Achaemenid" Empire (550-330 BCE) and The "Sassanid" Empire (224 CE to 651 CE) resulting in the changes in Iranian architecture. It also aims to explore the differences and the reasons of changes in the materials used for constructions and the influence that these changes had on the architectural style in the above mentioned periods.

Keywords:Achaemenid, Achaemenian, Sassanid, Sassanian,Pasargad, Susa, Perspolis, Qhal'eDokhtar, Sarvestan, architecture style, Parsi, Parti, Khorasani, Azari, Razi, Isfahani, material, Empire, History, Building, Flat Roof, Arched Roof, Arch, Dome.
\end{abstract}

I. The Achaemenid Empire:

In the sixth century BCE, the Iranian king-Cyrus the Great- established an empire called the "Achaemenid" Empire (/a'ki:mənıd/; Old Persian: Haxāmanišiyā; c. 550-330 BCE), or First Persian Empire[1] in central Western and Central Asia. Achaemenid Persian Empire was considered as the greatest empire on the earth in the ancient history then. It was dominant from Anatolia and Egypt across western Asia to northern India and Central Asia. It started to emerge when King "Astyages" of "Madia", ruled over a big area of Iran and eastern "Anatiolia" (Turkey) in 550 B.C... In that time, Persian king, "Cyrus" "the Great", (r. 559-530 B.C.), who was his neighbour in Iran, overcame him. It turned over the stability of power in the Near East. The benefit of the lost of Media in went to the "Lydians" of western Anatolia under King Croesus and made the Persian troops to move to east and to fight with the Persian troops. The Lydian army left the battle while Persians went forward to the Capital city of "Lydians" located in Sardis, surrounded it for two weeks and could defeat and conquer it.Before that Babylonians and Egyptians had allied themselves with "Lydians" therefore Cyrus needed to deal with the three important strong powers. Mesopotamia and the eastern Mediterraneanwere ruled by Babylonian empire. Persian forces won a victory over the Babylonian army at the site of "Opis", east of the Tigris in 539 B.C. Then political prisoners were freed and temples were returned to their original condition by Cyrus after he went to Babylon showing himself as a Mesopotamian King. Cyrus did not conquer Egypt. Butin 525 B.C. his son Cambyses defeated the Egyptian troops in Nile delta and after fighting for ten days, Persians overcame the ancient capital of Egypt, Memphis. 


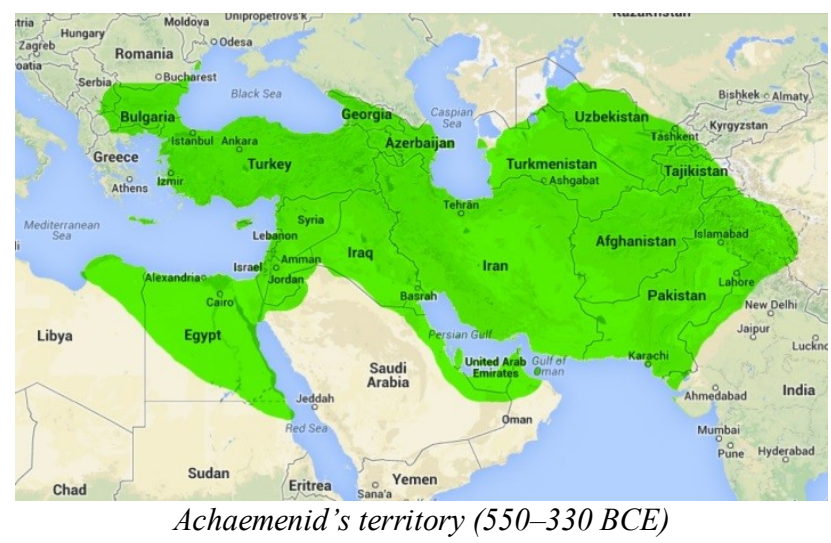

At that time, there was a great diversity of materials in Achemenidsdue to the empires in them. In fact they were considered as the resource of this diversity.In the time of Achaemenids, the source of materials across their empires were very great and various.As a result, a specific type of architecture emerged. In this style, odd materials were used that were different from the new architecture in Iran. A stone on which Darius I(Old Persian Dârayavauš) ("The Great") (r. 521-486 B.C.) the accurate information can confirm it.

"... Yaka timber was brought from Gandara and from Carmania. The gold was brought from Sardis and from Bactria ... the precious stone lapis-lazuli and carnelian ... was brought from Sogdiana. The turquoise from Chorasmia, the silver and ebony from Egypt, the ornamentation from Ionia, the ivory from Ethiopia and from Sindh and from Arachosia. The stone-cutters who wrought the stone, those were Ionians and Sardians. The goldsmiths were Medes and Egyptians. The men who wrought the wood, those were Sardians and Egyptians. The men who wrought the baked brick, those were Babylonians. The men who adorned the wall, those were Medes and Egyptians."

A piece of Darius Inscription on the variety and large quantity of Achaemenid's Architecture Materials

It was the first time that people saw such a great royal and glorious art. The artists as well as the materials were from all over that empire. Then, it was a diverse art formed by a combination of designs as decorations, styles, aptitudesthrough which the Persian Empire was reflected.

The information that Darius presented indicated that most of the material utilized then must have provided from outside Iran. As well a number of those working in Achaemenids constructions such as "Susa". "Perspolice" and "Pasargad" were from different countries such as Babylon, Greece and some other countries where their thoughts and opinions could influence the architecture then. Moreover, the extent and expansion of materials made construction of ambitious structures possible so that no buildings similar to them could be found for long while following the time that they were built.

In general, the features of Achaemenids architecture were due to the span of material. In that time, the roofs of the buildings were high and areas between the columns were wide. Some examples of Acheamidesarchitecture

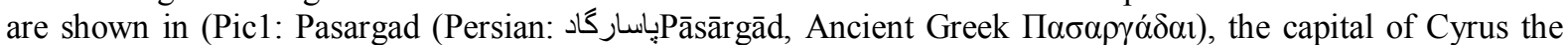
Great (559-530 BC)), (Pic 2: Persepolis (Old-Persian: Părśapura[2]) was the ceremonial capital of the

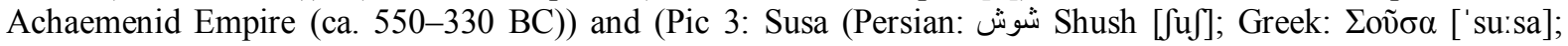

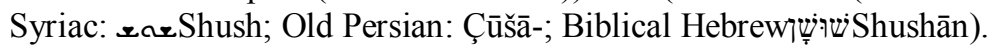

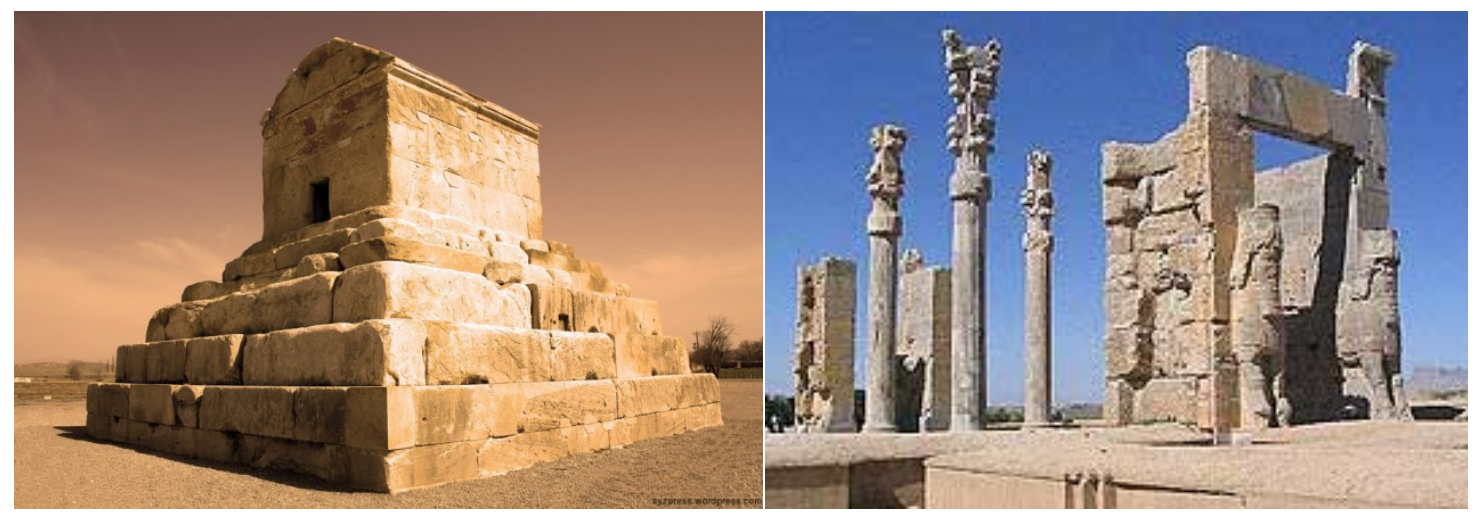

Pic 1: Pasargad

Pic 2: Perspolise 


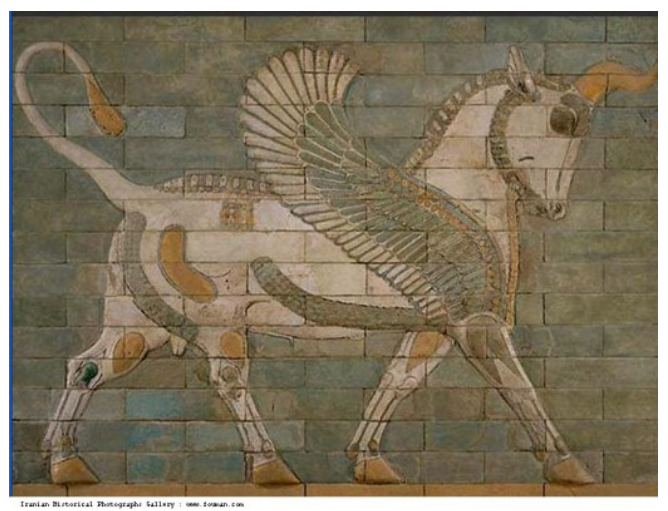

II. The Sassanid Empire:

Pic 3: Flying Bull Mosaic Susa

The residents of the Sassanid Empire (/'sæsənid/; also known as Sassanian, Sasanid, or Sassanid ) or Neo-Persian Empire,[3]knew it as "Ērānshahr" and "Ērān" in Middle Persian. This is why the final Iranian empire preceding the emerge of Islam, was addressed by the New Persian words "Iranshahr" and Iran [4]. That time, from 224 CE to 651 CE.[7][5], the "Sasanian" Dynasty were the rulers. For over 400 years [6], the Sasanid Empire, that was the next Empire after "Parthian" Empire, was one of the major powers ruling in Western and Central Asia while Roman-Byzantine Empire was another empire at the same time.

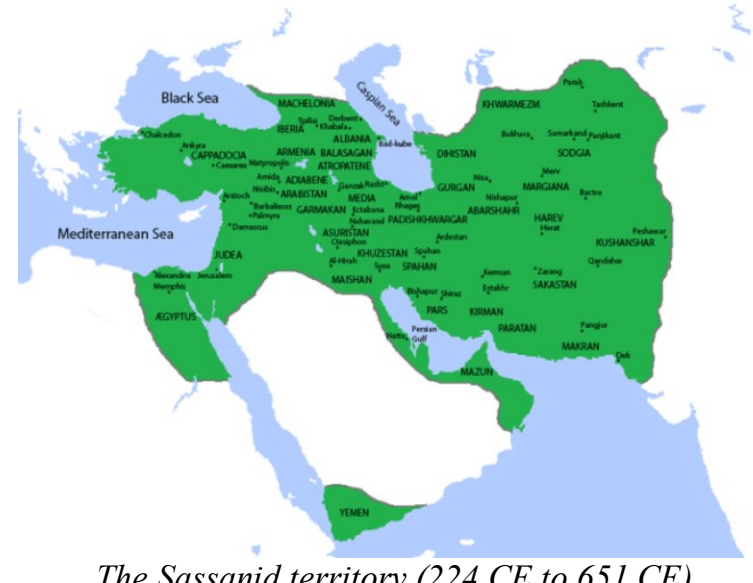

The Sassanid territory (224 CE to 651 CE)

Persian architectural style which was very successful with greatest achievement is improvement during the Sassanid era is considered as Sassanid architecture. In the time that Sassanid Empire was dominant (224-651 CE), most accomplishments were observed in Persian civilization in a lot of different approaches. In this period, before the Muslims invasion, the last important pre-Islamic Persian Empire was formed. Indeed, the Persians were the origin the culture, architecture, writing and some more skills which was later considered as Muslim culture, architecture and so on in a bigger extent in the areas dominated by Islam.

Similar to the Achaemenid Empire, the rules of the country in the Sassanid period started in the province of "Persis" (Fars). They believed that they took the place ofAchaemenians following the Parthin ruling had stopped and gave the responsibility to them to give the glory of Persia back to this empire.

However, as the territory Achaemerinas period was bigger than the territory in in Sassanid time, the materials available for Achemenianswere more and more various than what Sassanid could access. Moreover, the Achaemeniyans were more powerful than Sassanians and they did not exist in the same period of time, Achaemenians that were newer needed to make more constructions. Hence, newer local material had to be used as the substitution of the materials used before that time. Now the question is that what the most appropriate newer materials were?

Iran can be considered as one of the most significant resources of dust. Thus, the heavy and large stones could be replaced by bricks. Moreover, in order to utilize little bricks and for covering broad and long roofs, a different type of construction was needed. Then, two architects from Iran made two masterworks called the "Arches" and the "Domes"! In that period, two Iranian masterworks weredesigned for the first time.

The arches in Sassanid buildings were between 50 and 85 feet high. They used to be simple and there was not decoration. While in a single casethere are little arches around the big arch and the influence is satisfactory. The foundations of the arched apartments were in the shape of squares ranging between 25 and 40 feet or a bit over. The shape of the base of the arches was circle but a half ellipse should be seen in a part of them while the ratio 
of the longest and shortest diameters equals three or two. They were a bit higher than 70 feet from the ground. No building had more than three or twodomes whose sizes were similar or their dimensions were dissimilar.

Across the angles of the flat, there were some semi-circular arches. Every one of these arches projected more into the angles than the previous one so that there were not any corners and instead of having four 90 degree angles, there was a circle. Round each flat, above or/and below the pendentives, there was a cornice. There were some little holes in each dome.

The Sassanid palaces had no passages or corridors. Often, each room opened into another room. If the rooms did not open into the next room, there was a shared meeting-ground that was an open court or a big flat that was domed. Generally, the openings were doorways which were neither big nor small. However, at times the arches were as wide as their subordinate room or flat. In each place, there were about seventeen or eighteen rooms.

There was another alteration in Sassanid architecture related to plastering added to the architecture of the buildings. Indeed, since most surfaces in Achaemenid structures were formed by curved stones, plastering was not necessary in Achaemeniuansbecause carved stones can function as the plastering. In general, the arched-shape roofs and plastering were the accomplishments obtained directly dueto materials found in Sasamid period. The examples of such architecture in Sasanid period include : (pic 4, 5: Sarvestan (Persian: سروستان:Sarvestân, "land of cedars"; Sarv "cedar" (cypress) + estan; also Romanized as Sarvestān and Sarvistān)[8]) and (pic 6: Qal'ehDokhtar (Persian: قلعه دختر, "The Maiden Castle").

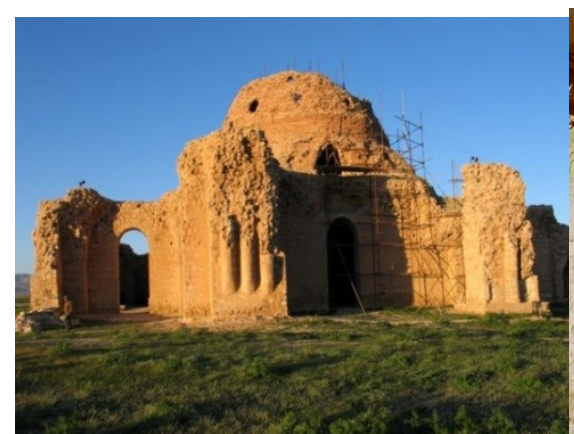

Pic 4:Sarvestan(land of cedars)

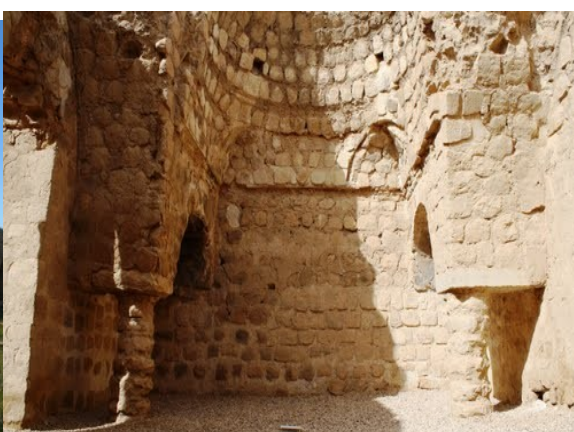

Pic 5: Sarvestan (land of cedars)

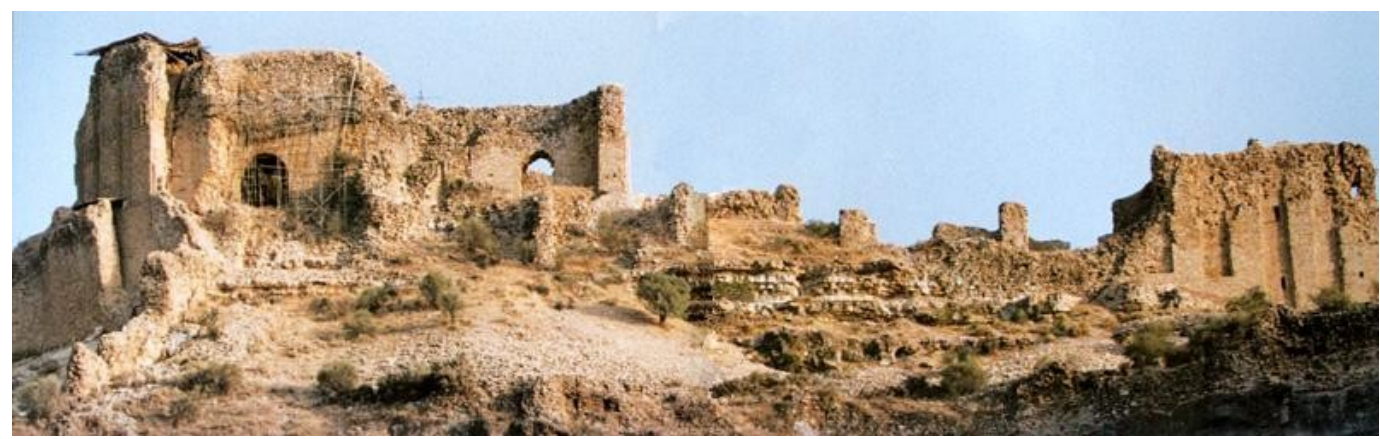

Pic 6: Qal'ehDokhtar, (The Maiden Castle)

III. Concluding:

Based on what was mentioned above, like Achaemenid, Sasanids possessed a great territory, but their economic situation was not as good as Achaemenid's, they were not as strong as the Achaemenid either. Moreover, as it was necessary for Sasanids to build more buildings, there was not enough time to act similar to Achaemenid that made Persepolis during as long as 150 years. There were some more justifications other than mental and theoretical reasons influencing the architecture then. These reasons brought new styles of architecture called "Parti style" today. Though the "Parti" style dealt with some restrictions, compared with the "Parsi" style, it did not have disadvantages and shortcomings more than "parsi" style because Iranian architecture was aware of the situations and could improve that style through new conditions in the most appropriate method so the new style was beautiful like the previous style.

This new style was not complete and there were some restrictions compared with the "Parsi" style, but its shortages were not as many as in the "Parsi" style, for the conditions were obvious and considered in Iranian architecture and were reformed optimally by the new style in the new condition so that the new style was as stylish as the previous one and it was also beautiful. 


\section{References:}

[1] Sampson, Gareth C. (2008). The Defeat of Rome: Crassus, Carrhae and the Invasion of the East. Pen \& Sword Books Limited. p. 33. ISBN: 9781844156764.

[2] Curtis, J. and Tallis, N. (eds). (2005). Forgotten Empire: The World of Ancient Persia. Universityof California Press. ISBN: 0-52024731-0.

[3] Fattah, HalaMundhir (2009). A Brief History of Iraq. Infobase Publishing. p. 49.ISBN 9780816057672. "Historians have also referred to the Sassanian Empire as the Neo-Persian Empire."

[4] MacKenzie, D. N. (2005), A Concise Pahlavi Dictionary, London \& New York: Routledge Curzon, p. 120, ISBN 0-19-713559-5.

[5] "A Brief History". Culture of Iran.Archived from the original on October 11, 2007.Retrieved 11 September 2009.

[6] SHAHBAZI, A. Shapur. Sasanian Dynasty. Encyclopaedia Iranica, 2005.

[7] Wiesehöfer, Josef. "Ancient Persia from 550 BC to 650 AD, trans." A. Azodi, London (1996).

[8] Sarvestan can be found at GEOnet Names Server, at this link, by opening the Advanced Search box, entering "-3083107" in the "Unique Feature Id" form, and clicking on "Search Database".

[9] All pictures resource is www.Wikipedia.com 